Etnográfica

Revista do Centro em Rede de Investigação em

Antropologia

vol. 25 (2) | 2021

Vol. 25 (2)

\title{
Emotions and religion across the Atlantic: senses and lusophone orixás
}

Emoções e religião através do Atlântico: sentidos e orixás lusófonos

\section{Clara Saraiva}

\section{(e) OpenEdition \\ Journals}

Electronic version

URL: https://journals.openedition.org/etnografica/10440

DOI: 10.4000/etnografica. 10440

ISSN: 2182-2891

\section{Publisher}

Centro em Rede de Investigação em Antropologia

Printed version

Number of pages: $465-492$

ISSN: 0873-6561

\section{Electronic reference}

Clara Saraiva, "Emotions and religion across the Atlantic: senses and lusophone orixás", Etnográfica [Online], vol. 25 (2) | 2021, Online since 29 July 2021, connection on 20 January 2022. URL: http:// journals.openedition.org/etnografica/10440; DOI: https://doi.org/10.4000/etnografica.10440

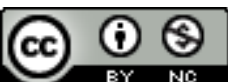

Etnográfica is licensed under a Creative Commons Attribution-NonCommercial 4.0 International License. 


\section{Emotions and religion across the Atlantic: senses and lusophone orixás}

\section{Clara Saraiva}

For the past 30 years, the Afro-Brazilian religions have crossed the Atlantic, reaching Portugal. One of the aspects that the Portuguese find most appealing is the possibility of expressing their emotions freely, either through possession and the incorporation of entities whose performances are directly connected with a sense of emotional freedom, or because these religions proclaim a clear openness and acceptance of different races, sexual preferences or even other religious beliefs. Nevertheless, the process of becoming initiated as well as the ritual sequences are both strongly hierarchical, obeying norms that should not be transgressed in order to advance in one's religious career. Split between such contradictory emotions, individuals manage them as a means to negotiate their identities within the religious group and outside of it (Wulff 2007). I will expand on the issues of emotional behavior, performance, and authenticity, connecting them with the case-study of the expansion of the Afro-Brazilian religions in Portugal. In order to do this, the performative side (Beeman 2007; Schechner and Appel 1990) of these religions and the relationship between emotions and issues of authenticity - anchored on the seminal work compiled by Thomas Fillitz and Jamie Saris in the book Debating Authenticity (2013) - will be discussed.

KEYWORDS: Afro-Brazilian religions, Portugal, ritual and performance, emotions, authenticity.

Emoções e religião através do Atlântico: sentidos e orixás lusófonos • Nos últimos 30 anos, as religiões afro-brasileiras cruzaram o Atlântico, chegando a Portugal. Um dos aspetos que os portugueses consideram mais apelativos é a possibilidade de expressar livremente as suas emoções, quer através da posse e incorporação de entidades cujas atuações estão diretamente ligadas a um sentimento de liberdade emocional, quer porque estas religiões proclamam uma clara abertura e aceitação de diferentes raças, preferências sexuais ou mesmo outras crenças religiosas. No entanto, tanto o processo de iniciação como as sequências rituais são fortemente hierárquicas, obedecendo a normas que não devem ser transgredidas para avançar na carreira religiosa. Divididos entre essas emoções contraditórias, as pessoas gerem-nas como um meio de negociar as suas identidades dentro do grupo religioso e fora dele (Wulff 2007). Discutem-se aqui questões de comportamento emocional, performance e autenticidade, relacionando-as com o estudo de caso da expansão das religiões afro-brasileiras em Portugal. Para fazer isso, o lado performativo (Beeman 2007; Schechner e Appel 1990) dessas religiões e a relação entre emoções e questões de autenticidade - ancorada no trabalho seminal compilado por Thomas Fillitz e Jamie Saris no livro Debating Authenticity (2013) - será igualmente analisada.

PALAVRAS-CHAVE: religiões afro-brasileiras, Portugal, ritual e performance, emoções, autenticidade.

SARAIVA, Clara (maria-saraiva@campus.ul.pt) - Center for Comparative Studies, FLUL, University of Lisbon, Portugal. 


\section{RELIGIOUS FREEDOM AND NEW RELIGIOUS EXPRESSIONS}

After decades of political dictatorship, the 1974 revolution brought freedom to Portugal - and had broad repercussions. ${ }^{1}$ The country opened up to new ideas and new practices. One of the consequences was that, especially with the country's accession to the EU in 1986, Portugal went from being a country of emigration, to a destination for immigrants. The migrants brought with them their world views and religions, enriching the Portuguese religious panorama. ${ }^{2}$ Protected by the Constitution and laws concerning religious freedom, the religious variety grew beyond the Catholic and other religious affiliations which, although minority ones, had an historical presence in the country, from Jewish to Islamic and Evangelical congregations (Vilaça 2006). To these were added, in the last decades, Pentecostal and neo-Pentecostal groups (Mafra 2002), some African prophetic churches (Blanes 2009; Sarró and Blanes 2010) as well as other practices imported by diverse African migrants (Saraiva 2007, 2008, 2010a, 2016), Afro-Brazilian religions (Bahia 2015a; Bastos 2001; 2015b; Guillot 2009; Pordeus Jr. 2000, 2009; Saraiva 2008, 2010c, 2016, 2019), Orthodox (Vilaça et al. 2016), Buddhist, Punjabi Sikh or Hindu temples and also neo-pagan, neo-shaman and neo-druid groups (Fedele 2013; Roussou 2017).

The Afro-Brazilian cults are part of this cluster of recent, diverse religioscapes. In the last 30 years they have widely expanded, and there are currently over 50 terreiros in the country. ${ }^{3}$

This text, based on field work done in Umbanda and Candomblé terreiros in Portugal, including participant observation and extensive interviews with cult leaders and their followers, discusses certain aspects of the expansion of these cults, focusing on the way emotions are handled by both practitioners and clients of such religions.

I argue that the success of the Afro-Brazilian cults in Portugal must be understood in the context of the attraction to a new religion that provides for greater individual visibility and prestige. The opportunity to overtly show one's emotions and the way this can be used as a means of empowerment within the religious community will be explored. The way emotions are handled within the religious context relates to questions of performance and authenticity: are the emotions exposed in the ritual contexts real ones or staged and connected with performance? What is "real" and what is "fake", especially when altered

I This article is financed by national funds through FCT - Fundação para a Ciência e a Tecnologia, I. P., in the context of the project UIDB/00509/2020.

2 Research has been done on the recent condition of the country as a host-nation for migrants from other continents; see, among many others, Barreto (2005), Machado (2002), Malheiros (2005), Vala (1999).

3 Terreiro refers both to the temple and the religious community. 
states of consciousness (ASC) are involved? What, indeed, is the degree of freedom in such religions, and how is it perceived by a population that has only recently come into contact with them?

The emotional turn in Anthropology (Briggs 1970; Lutz and White 1986; Lutz 1988; Lutz and Abu-Lughod 1990; Hoschild 1983; Myers 1979; Rosaldo 1984) definitely showed how emotions are culturally and historically specific and stressed the importance of cross-cultural variation in the socialization of emotions. Furthermore, the various studies on emotions have suggested that the traditional contradictory views on emotions as either universalist biological or culturally constructed phenomena should be combined (Svasek 2005: 2), as emotions also weave into cognition and biology (Wulff 2007: 1). Other authors, following the guidelines of the reflexive turn, stress the importance of empathy (for instance, between the fieldworker and those we research, as anthropologists), since, as Helena Wulff stresses (2007: 3), we all have feelings.

Emotions, whether as part of specifically devotional activities or in connection with the everyday behavior of religious individuals, can be considered integral to the practice of religion (Corrigan 2007: 8). This text is about feelings and senses when related to religion. More precisely, when related to specific religions that have triggered innumerous reflections on the connection between religion, altered states of consciousness and emotions. The focus will be on the case of the expansion of the Afro-Brazilian religions in Portugal, analyzing some aspects that are deemed important in the relation between religion and emotions, using both previous anthropological literature on the themes, and data from fieldwork carried out in Portugal over the last fifteen years. ${ }^{4}$

Such issues include: how the Afro-Brazilian religions are considered the epitome of religions in which the senses are of the utmost importance; how they are often seen as tolerant religions, insofar as accepting individuals with various emotional and sexual orientations; and the fact that their tolerance is actually simply the other side of the coin to the rules and duties one needs to abide by as a practitioner. Such issues will bring us to another one, anchored on the seminal work of Thomas Fillitz and Jamie Saris Debating Authenticity (2013): that of the concept of authenticity in religion, which ties into the debate on ritual and performance (Beeman 2007; Schechner and Appel 1990).

\section{EXPRESSING EMOTIONS, INCORPORATING ENTITIES AND GODS}

In a book discussing the transnational religious and social dynamics of the African diaspora, Afe Adogame and James Spickard (2010) argue that Africa

4 Research has also taken place, during the same time span, in Brazil, for comparative purposes and in order to understand the roots and connections between Portugal and Brazil (see, for instance, Saraiva 2019). 
was in the past - and continues to be - a major centre for religious vitality. The Afro-Brazilian religions are a good example of such vitality and transnational religious circulation. The history and sociology of the formation of these religions were analysed in the classical works of Roger Bastide and Pierre Verger, among others. These authors showed how the cults of the different gods in the original African contexts were, through centuries of slave trading, exported to the New World, developing into a wide variety of new re-organized cults, which brought together three cultural and religious matrices - the African religions, Catholicism and native Amerindian practices. In contemporary Brazil there is a large variety of sub-cults, from the Catholic and Kardecist related Umbanda practices, to the more Africanized Candomble keto, corroborating what several authors have analysed concerning the religious continuum of such Afro-Brazilian religious clusters (Capone 2004b; Frigerio 2004). As Alejandro Frigerio states (2004: 44), we can consider the cults closer to that Catholic matrix as cognitive bridges between the folk Catholicism that is traditionally practised and the more African variants that have some theological concepts and rituals that are unfamiliar to it.

With the expansion beyond the Brazilian borders, first to other regions in the Americas, and later to Europe, the plasticity of such religions has been especially put to the proof, since they have had to adapt to new types of followers, new settings and new social and cultural circumstances (Frigerio 2004; Oro 1995). ${ }^{5}$

In the history of the expansion of the Afro-Brazilian religions to Portugal two aspects must be taken into consideration: the fact that such religions have their roots in Africa, and that Brazil was the setting in which they grew and transformed into what they are now. As such, the linkage to both Africa and Brazil is invoked by pais and mães-de-santo and in Portugal there are currently several types of cult leaders. In the first group are Portuguese that were immigrants in Brazil and were initiated there; there are also other Portuguese who, having become interested in such religions, went to Brazil in the pursuit of knowledge to become priests themselves. In the second group are Brazilians, who either came to Portugal to work or, having connections here, came here expressly to open their own terreiros, and instruct followers to do the same. There is also the case of Brazilians who come occasionally for short periods of time to give consultations (búzios) and then leave shortly after, without

5 See Oro (1995), Oro and Steil (1997), and Frigerio (2004), for the expansion to other Southern American countries; Capone (2004a, 2004b, 2011), and Schmidt (2008), for the United States; Guillot (2009), Teisenhoffer (2007), Halloy (2001-2002), Rossbach de Olmos (2009), Bahia (2012, 2020), Saraiva (2010a, 2010b, 2010c, 2013a, 2013b, 2016), for a sample of the European cases. 
creating a true religious community, illustrating what Pordeus Jr. (2009) calls, following Victor Turner, the "anti-communitas". 6

In spite of the large number of Brazilian immigrants in Portugal, ${ }^{7}$ it is the Portuguese who are drawn to the Iemanjá and become followers of such cults; ${ }^{8}$ the great majority of individuals in the terreiros are Portuguese, who often grew up in Catholic environments. If we systematize the reasons for the success of the Afro-Brazilian religions among the Portuguese, following Ari Oro's suggestions (Oro 1995), as I have done elsewhere (Saraiva 2010a, 2010b, 2010c), we can see that they belong mainly to two sets: the first one concerning their nature and the second one concerning the use that people make of these religions. Such reasons suggest both continuities with the old Portuguese world of popular religion, ${ }^{9}$ while, at the same time, new and appealing features are added to the scenario.

They are strong religions of affliction; certainly, all religions address their members' day-to-day, existential problems and see the benevolent spiritual entities as helping people in their everyday lives. Nevertheless, the Afro-Brazilian ones truly address life-crisis situations, providing individuals with an immediate interpretation and response to their ailments, either through the cowrie shell divination system as in Candomblé, or through direct consultation with a supernatural entity as in Umbanda. As such, most of the time adherence to these religions starts with seeking consultations to overcome affliction situations related to health, love or financial troubles. From this perspective, individuals often reinterpret their problems through the lenses of their new appurtenance, and by reviewing their cognitive maps of rejection/inclusion within certain worldviews. If healing is definitely an important aspect (Saraiva

6 There are also ritual leaders claiming a direct relationship with Africa; these are individuals who came directly from the former Portuguese colonies in Africa, especially Angola. I have discussed such cases in other texts (Saraiva 2013a, 2013b).

7 They represented ca. $25.6 \%$ of the migrant population according to the 2019 SEF (Serviço de Estrangeiros e Fronteiras) report. Available at < https://sefstat.sef.pt/Docs/Rifa2019.pdf > (last access June 2021).

8 The fieldwork conducted for this paper took place in several Candomblé (3) and Umbanda (5) temples in the class. The presence of individuals of African ascendency (for instance, from the former Portuguese colonies) is very low (an average of one to three individuals per terreiro). The Greater Lisbon area and in the Northwest of Portugal. Although some cult leaders and ogãs (drum players) are Brazilian, most of the followers are Portuguese. The individuals who engage as initiated, the followers and clients of these religions are, in their great majority, white, Portuguese middle, and same happens with Brazilians, who, in their majority, join Pentecostal and neo-Pentecostal religions (Saraiva 2010a, 2010b, 2010c). As in Brazil, in Portugal there are terreiros more directed at an upper middle class, but the vast majority have a frequency based on mixed middle class individuals. These individuals come mostly from a Catholic matrix, but many have also tried other forms of new religiosities, as I explain further on.

9 In the sense used by Favret-Saada (1977) as a mixture of Catholicism with popular believes in witchcraft, etc. 
2011 ), in this new approach directly connected to their adoption of the new cults, the solutions for crisis are attributed to the conversion to the cult of the orixás (Saraiva 2013a, 2013b).

Highlighting both the individual and the collective aspects, they favour the construction of a personal and collective identity and trigger self-perceptions of integration into a group. The Saturday gatherings at the Umbanda terreiros, where people bring food and drinks for a big collective meal after the session, or the ajeum (collective meal) after the long hours of the xirê, imply all the social aspects of commensality in ritual, when people come together in an informal way and feel that they belong to a religious community, the familia-de-santo (literally, family of the saint, where the pai or mãe-de-santo are the religious leaders, and the followers are their symbolic sons and daughters, filhos/as-de-santo).

Most important, they are religions of seduction that cultivate the mysterious aspects of their performances, based on an historical idea of the relation to Africa and the magical powers of African religions. ${ }^{10}$ Part of their seduction lies in an aesthetic side connected to the visual splendour of ritual performance. This is mostly present in the Candomblé xirê, when the orixás come down and dance, dressed in their colourful and wonderful attire. The Portuguese are thus attracted to the aesthetic side of their conversion to the religions of the orixás. Connected with this seduction is the fact that they are what several authors have called "emotional religions", in the sense that they allow for the individual expression of emotions and emotional catharsis. The emotional aspect ties in with the value given to the possibility of entering trance and the empowerment that becoming possessed by powerful divine entities provides. These aspects are central to understand the success of these religions in Portugal.

\section{EMOTIONS AND EMBODIMENTS}

In his piece "The study of religions and emotion", John Corrigan (2007) expands on how emotions, whether as part of specifically devotional activities that are undertaken at sacred sites or in connection with the everyday behavior of persons, need to be seen as integral to the practice of religion.

A person learns, throughout his/her life, to experience the world through all the senses; as far as religions are concerned, some focus more on such sensorial experiences than others. In the Afro-Brazilian religions, the world is indeed apprehended through the five basic senses: what you smell, hear, see, touch, and taste. In any xirê, the cyclical feasts that honor an orixá in Candomblé, and

10 The idea of an historical and cultural connection across the Atlantic, linking Africa and the New World - in this case, Brazil - is certainly valid for the case of the Afro-Brazilian religions, as J. L. Matory has expanded on in his book Black Atlantic Religion (2005). 
its ritual sequence, we can easily trace these five senses: one smells the odor of the plants burned to clean the spaces and attract good energies, before the ritual starts; one hears the sound of the drums and the chants that mark the beginning of the performance, induce incorporation and continue throughout the ritual, setting the pace for the dances, from calmer to more frenetic ones; one sees the splendorous performance that is a xirê, with all the orixás incorporating their horses, dressed in the colorful and rich ritual attire; one is touched by the orixás, as they embrace both the initiated and standers-by; and finally, one tastes the comida-de-santo, ${ }^{11}$ at the final common meal, the ajeum, when the performance is finished. All these constitute, in the ritual setting, highly elaborate, conversationally and ritually salient ways of experiencing the senses (Brenneis 2005: 142-143).

This is stressed in the interviews in Portugal, as pai-de-santo J., a Candomble religious leader, stated: "Whereas in other religions we approach the spiritual (God) mainly by faith, in the Afro-Brazilian religions, especially in Candomblé, besides the faith, we do indeed see the orixá. In Umbanda, we also see and talk directly to the spiritual entities".

The same idea is corroborated by C., an Umbanda pai-de-santo:

"The biggest tool in the Afro-Brazilian religions, and in Umbanda, is the emotional connection between the orixá and the entity and between the entity and the client $[\ldots]$ when people start attending these religions, they get here through emotion, which is an indispensable factor in religion; much healing is achieved in a hug, a look, an exchange of emotions, happiness or sadness; people need to feel that someone is taking care of them, just as the spiritual entities do." [Pai-de-santo C.]

This emotional relation also involves creativity, as Corrigan (2007: 8) puts it: "Of particular importance is the place of emotions in the creative and imaginative aspects of religious life - how music, for example, or sexuality, or the production of material culture are shaped through appeal to feeling [...]".

Part of this emotional involvement comes from the fact that the Afro-Brazilian religions are religions where the initiated enter altered states of consciousness. The capacity to enter trance is highly valued and is crucial to the whole religious system. Travelling across the Atlantic, the Brazilian divinities are summoned into the presence of the living (Saraiva 2019). In Candomblé, the orixás (deities), descend upon their horses, incorporating them, dancing and blessing everyone with their presence. The dance is a powerful tool, as the orixás dance for hours (sometimes the whole night). As Matthews states, relating his own reflections to Saint Augustine's thoughts on ritual and religion,

11 Literally, food of the saint, since each orixá has his/her specific ritual dishes. 
"the intensification of a religious attitude or feeling by the performance of a ritualistic act is a case of movement of the body having the effect of moving the soul" (Matthews 1980: 340).

In the Umbanda case, the entities that are archetypes of Brazilian society - such as old black slaves (pretos-velhos) or indigenous Brazilians (caboclos) and female exu spirits - spread the practice of charity, giving consultations to the clients who come in search of help for their ailments. ${ }^{12}$

In fact, a simple observation of a xirê or gira session allows the anthropologist or anyone to observe a great degree of bodily interaction and physical expression of emotions. In the xirê, the orixás descend, dance and bless the people with their divine presence; being gods, they do not talk to the humans, but they do hug them, thus metonymically transmitting their strength and energy. It is a source of pride to be hugged by an orixá:

"Even after the xirê was over, for days the image and warmth I felt when Oxum hugged me accompanied me and helped me through my toughest moments. And although many years have gone by since that very first experience, I still remember it as one of the most wonderful ones in my life."

In Umbanda, the direct interaction with the entities that descend allow not only for touching and a great deal of bodily interaction, but also for a verbal interaction: ${ }^{13}$

"Being able to explain my problems to the preto-velho, having him patiently listening to me, advising me on what to do, while he held my hands and caressed them, gave me a sense of peace and I felt my troubles would really vanish." [Interview, Umbanda follower]

Empowered by their new condition of incorporating gods and sacred entities, individuals also feel that these religions allow for a free expression of emotions that is crucial to their expansion, as one interviewee (follower of Candomblé) mentioned:

"[...] In the xirê, when an orixá hugs you, you feel a special emotion, because you are being touched and blessed by a God; but even after the

12 The $е x u$ are entities included in the Umbanda cosmos, perceived as a force to counterbalance the evil in the world (Schmidt 2016: 31). Female exus (pombas-giras) are often (but not always) perceived as prostitutes.

13 In Umbanda the orixás do not descend through the medium; the emotional force of the orixás is meant to be too strong and therefore they cannot speak through a medium's body; a medium would explode if possessed by an orixá (Pressel 1973: 285, in Schmidt 2016: 30). 
ceremony is over, there is also a sense of joy, an atmosphere that one feels comfortable with... and makes you want to go back and stay, the more you get into the cult."

\section{PARADISE ON EARTH? CONTINUITIES AND DISCONTINUITIES}

Afro-Brazilian religions, and especially Umbanda, are known to be tolerant towards other religious affiliations. Often individuals attend the gira on a Saturday and Catholic mass on a Sunday (Saraiva 2010a, 2010b; Schmidt 2016). The religions are also advertised as religions where there is no Cartesian dichotomy between right and wrong, no notion of evil and sin. This undoubtedly attracts individuals who feel that they have been submitted, all their lives, to the authority of Catholic priests who blame them for misbehaving and not thinking and acting according to God's doctrine. As such, they are praised as religions that allow for a free reconstruction of the self, bringing together outcasts, personified in the gods that are part of the pantheon or in the life stories of the supernatural entities. The list of historical outcast characters is immense, and ranges from women and homosexuals to gipsies, prostitutes, tricksters and drunkards.

One of the first texts that dealt with the issue of how Afro-Brazilian religions empowered categories that would otherwise be left in their underplayed position was Ruth Landes' The City of Women, originally published in 1947 (Landes 2002 [1947]). Landes, an American anthropologist, went to Bahia in the late 1930s with the objective of studying "the blacks" but ended up doing fieldwork in the two most prestigious Candomble terreiros in the city, Gantois and Casa Branca do Engenho Velho. The book came out as an appraisal of the role of women in these religions, as she argued that Candomble gave both women and homosexual men a position of power and enabled them to express and develop their creativity, thus establishing a link between social marginalization and religious activities, in particular spirit possession (Schmidt 2016: 47-50).

The debate about women's predominance in possession rituals in Brazil has been a long one, with Lewis (2003) and other scholars pursuing the line of thought that relates ecstatic religious experience and possession rituals to women and marginalized groups, who are deprived of their rights, as an instrument that provides such groups (that have no other means of assertiveness) a great deal of empowerment. This debate invokes Janice Boddy (1989), affirming that it is possible to be peripheral in the political arena but central in another sector of society; Bourguignon (2004), defending women's role as a psychodynamic response to their powerlessness; Matory (2005), reacting to Landes' perspective of Candomblé as matriarchal; Chestnut (2003), explaining the higher number of female participants in Umbanda based on the therapeutic function of this religion; or Stefania Capone (1999: 182), who analyses the 
role of the female exu pomba-gira as enabling women to act when confronted with violence by men. ${ }^{14}$

Landes discovered the Bahian Candomblé through Edison Carneiro, ${ }^{15}$ at a moment in the history of Brazil marked by the Vargas dictatorship, when it was not easy to be a practitioner in these religions, much less to be a foreigner, and a woman, interested in them. Her book is full of impressionist and sensorial descriptions of the terreiros, where we can smell the scents, see the colors and the aesthetics of such environments; such vivid images clearly show her attraction to these religions and their practitioners. ${ }^{16}$ Being a double outsider (a foreigner and a woman), Landes nevertheless goes much further than most of the work done up until that time in Brazil, and it is important to recognize that, as Peter Fry states in his presentation of the second Brazilian edition of the book, she touched upon what Fry calls "three anthropological wounds of that time: the status of women in Brazilian society, the place of Africa in the interpretation of 'black culture' in the New World and the relationship between masculine homosexuality and Afro-Brazilian religiosity" (Fry 2002: 24).

Landes' approach can be considered a pioneer work in the sense that the fascination the author feels towards these religions, where the sensorial and aesthetic aspects are emphasized, is evident in her descriptions of field work. As Abreu (2003) points out, The City of Women was written in the contraflow of the scientific tendencies of the late 1940s. She revitalized the narrative style and constructed a way of making anthropology marked by the valorization of the field work experience, the sensibility towards gender issues, the senses and the affirmation of the singularity of the individual in the process of the construction of knowledge. ${ }^{17}$

If Landes' book triggered vivid discussions, we have come a long way, and the present-day scenario, in the $2 \mathrm{l}^{\text {st }}$ century, is that of a far-reaching western fascination with these religions. The structural position of former outcasts within society has also changed. Women have definitely become more empowered, and other social categories (such as homosexuals or LGBT), that would not even have been recognised in the 1940s, have conquered a rightful position

14 Just to mention a few authors involved in this long-standing debate. For a thorough revision and analysis of this discussion, with particular focus on the role of women, not only in the Afro-Brazilian religions, but also in other religions with possession cults, see Bettina Schmidt (2016: 47-91).

15 A journalist who had written several books on the African populations and religions - Religiões Negras (1936); Negros Bantos (1937) - and who organized in 1937 the Second Afro-Brazilian Congress, in which both Brazilian intellectuals and religious leaders of several Candomblé houses came together to discuss the past and future of those religions.

16 See, for instance, her visit to the 80 year-old babalorixá Martiniano Eliseu do Bonfim, her description of the neighborhood and of his house, where one can smell and be guided by the scents in her account.

17 Essentially, she did what several authors (Marcus, Rabinow) would only do almost 40 years later. 
in contemporary western society. The discourses of religious leaders, followers and clients portray a scenario where individuals feel at ease, not being confronted with notions of homosexuality as something wrong or disturbing, ${ }^{18}$ as these four excerpts from my field work interviews denote:

"In these religions there is no racism, no discrimination because of race, religious creed or sexual preferences [...]. There is a great sense of freedom, a great opening to homosexuals, to people with different beliefs." [Interview, Candomblé follower]

"LGBT are sensuous and sensitive individuals; emotions are here, open to be seen by everyone. Being in the Afro-Brazilian religions allows me to show these emotions freely, feeling good in my skin [...] I grew up being scorned by other male children, by my family, by the [Catholic] church I was brought up in... things changed when I found my família-de-santo." [Interview, Umbanda follower]

"In the Afro-Brazilian religions everyone has a place: homosexuals, transsexuals; it is wrong to think that a transgender is less worthy of receiving an orixá. Just as we are also open to all sorts of people: I could have been a murderer and want to redeem myself. For us, what matters is not what the person was, but what she/he wants to be... it is the religious commitment that transforms the emotions of the individual, the emotional relationship with the orixá." [Interview Pai J.]

"I became a woman because I felt like a woman encapsulated in a man's body; although to my orixá what matters is my origin as a male, in the terreiro everyone treats me as Mãe G.; this shows the emotional attachment my filhos and filhas have towards me, and how for them I am indeed a mãe-de-santo... it does not matter what I was when I was born, but what I am now." [Interview Mãe G.]

Nevertheless, the notion that the terreiros are a peaceful paradise for homosexuals has been much discussed and deconstructed, as several authors point to several forms of gender discrimination and hierarchical subjugation within the terreiros (see for instance: Fry 1982, 1985; Santos 2008; Matory 1988; Moutinho 2013). Such ambiguities lead us to the reflection on rules and duties in the terreiro, and how they relate to emotions. 


\section{ROLES, RULES AND DUTIES}

All the discourses and texts appraising the Afro-Brazilian religions seem nevertheless to forget that, on the other hand, they are also highly hierarchical and have extensive rules dictating the way people must behave. The whole process of being part of the povo-de-santo is a long apprenticeship on what to do, when, towards whom, on how to control your body, your gestures, on how to learn to become something else, domesticating (using the expression common in Haitian voodoo) the spirit that possesses you. The social construction of the person is structured around the myths that tell the story of the lives of the orixás, the relations between human sexuality and mythical sexuality, as the orixás become crucial classificatory referents for the organization of social relations (Barros and Teixeira 1989), acting as archetypes for the way to behave, to move, and to embody the relationship each person has with his/her orixá de cabeça. ${ }^{19}$ Ritual possession implies a whole set of strictly defined performances, following the rhythm of the sacred drums and chanting, wearing the clothing and paraphernalia that identifies a certain orixá or entity. As Beeman states, performance aims to change the cognitive state of the participants, and happens within culturally (and religious, I would add) defined cognitive frames that have identifiable boundaries (Beeman 2007: 275).

The situations requiring very rigid rules that demonstrate the hierarchy within the terreiro and within the ritual sequences are countless, and I will here expand on just a few of them. This happens, for instance, in the beginning of the cult sessions, when individuals have to bater a cabeça to the altar, for the pai/mãe-de-santo, as well as for the sacred drums; during the cult session, when everything is directed and orchestrated by the beating of the drums, the specific chants, the pontos cantados; but also, during the initiation process, when the iâ̂s get out of reclusion and publicly state their condition of submission to a new order and a new condition by keeping their heads low.

In the first instance, the act of bater a cabeça is literally to lay with the belly flat on the floor, touching the floor with one's head. This is done as a way to salute and as a sign of deference to these entities conceptualized as sacred: the cult leader, pai or mãe-de-santo, whom one must treat with the utmost respect; the sacred drums, since they are the sacred vehicle that call the divine entities into the ritual scenario; and the altar, where the images of the gods (orixás) are present.

During the ceremonies, the beating of the drums is joined by the chanting, ${ }^{20}$ which also induce the supernatural entities into coming down from the orum (the world of the supernatural, where the orixás live) and incorporating the humans. Each orixá has its own rhythm of drum beating, its specific chant, its own dress attire and its own body language. As such, the dance of the orixá

19 The orixá that owns the person, and directs her thoughts and emotions, acting also as a guardian angel.

20 Normally in Yoruba in the Candomblé sessions, or in Portuguese in the Umbanda cults. 
Oxum, the goddess of beauty and love, dressed in a beautiful yellow or golden dress and carrying a mirror in her hand, will be different from the dance of Ogum, the warrior god, wearing a blue outfit and holding a sword in his hand. All this is previously defined, and the process of being initiated is a process of learning about all the roles and duties.

When the iaô comes out of the reclusion period that ends the rite of passage he/she must go through to be fully initiated, he/she comes out of the roncô (sacred reclusion/initiation space) with his/her head down, showing once again submission and deference in the face of the cult leader and the congregation. Following the well-known structure of the rites of passage, the iâ comes out humble, as a child that has just been born and needs to make his/her way into the world.

\section{THE EMOTIONAL DARK SIDE OF THE FORCE}

How do the Portuguese, being part of a transnational and post-modern condition, see themselves as individuals and also as part of such groups? How do they construct their identities as cult followers and as part of a global society, as more and more individuals from different cultural backgrounds and various socio-economic strata become attracted to these religions? Do they experience their condition as ambiguous, or do they feel there is indeed a continuity between the awareness of being conscious and the condition of the unconscious self that possession implies?

The expression of emotions is, as mentioned, directly related to ritual possession, in the sense that, once incorporated, the individual is no longer oneself, but someone else, a god or a divine entity. Although such deities and entities are highly respected, some of them may be inconvenient, behaving in obscene and lascivious ways, talking to people using language otherwise considered socially ill-mannered.

The entities that personify the female gipsy, and the female prostitute (the Umbanda pomba-gira), or even the trickster and drunkard malandro all fall into a vast category of the exus, a highly problematic category within the AfroBrazilian religions. The exus tend to drink a lot, act as drunkards, and use inappropriate terms to address others. Talking out loud in a highly disrespectful manner, recurrently exhibiting obscene language and bodily behavior, but terribly powerful, these entities come down in ritual sessions generally named giras de esquerda in Umbanda (left side, meaning, the dark side), attracting a high number of followers and clients who want to invoke the "dark side" of such religions in order to manipulate or regain control of their lives. ${ }^{21}$

21 Exú is originally one of the orixás and it is in this category that he is venerated in Candomblé. Several authors have extensively discussed the modification of the African exu into an evil entity at the hands of Catholic missionaries and Catholic moral; see, for instance Silva (1995). 
The giras de esquerda, although feared by many followers, are in the end quite popular - and appealing - as situations "when one can hear the whole truth, no matter how bad it is. Zé Pelintra is really harsh, and it is hard to listen to him say those things about your private life in public, especially using rude words, but that is the way he is, and he tells you everything up front. That is also why he is so powerful and can make your man go back to your bed!" [interview, client, Umbanda].

As for the emotions of the medium him/herself, how does one feel after having incorporated for a few hours and realizing (although not conscious of what exactly he/she said or did while the entity was incorporated) that his/her exu or pomba-gira might have said or done things considered by normal social patterns as rude or inappropriate? The emic answers to such questions lie in the emphasis of emotions, and especially on the "emotional work" (Hoschild 1983) one needs to go through throughout his/her religious career:

"The medium has to have an emotional relationship with the spiritual entity; it is the work of emotions, but one has to learn to master this. The medium needs to be emotionally well balanced to handle all the difficult situations. So, I do not feel embarrassed if I know that my exú says swear words all the time and gets drunk. It is him, not me; it is the emotional entity that is in me, not my body. I am just the horse for the spirit. The proof is that my exú drinks a lot, and when he leaves, I am not drunk. Anyway, I cannot drink due to medical reasons, and I never drink. When I incorporate my exú, he drinks, but I do not get drunk. When the spirit leaves, he takes all the alcohol with him. But one has to learn to master such states, what is physical, what is emotional... it takes many years to learn to master all this." [Pai J.]

"Incorporating is very hard work, but very gratifying, and people must not feel ashamed of what they did while incorporated; that would be to deny the very principles of our religion." [Pai Jm.]

The same happens to a lesser extent in the incorporation of êres (ibeji), spirits of children that possess men and women and make them behave as small children. They generally come down at the end of the cult session; since they are spirits of small children, they are meant to be pure (as children are) and therefore are supposed to clean up the atmosphere from negative energies, bringing joyful and positive energies to the group after the gira. Several of my interviewees mentioned that, although it is nice to know that their êre has incorporated in them, they feel "funny" knowing they have gone around crawling on the floor, sucking a pacifier, playing with soft toys and fighting each other over candy: “... but we know it is the work of the orixa and the entities, and there is no harm in that. One of my filhas-de-santo said that if she had not seen my erêe, playing on 
the ground as a two-year-old child, she would not believe I could become that... but that is how it is, and afterwards we all laugh about it" [Pai Jm.].

So, there are two sides to this: on the one hand individuals feel attracted to such religions and the possibility of entering trance, turning into someone else, becoming powerful, but at the same time fearful of what may happen, what they may say or do, whether they will later feel ashamed. How are such problems solved? According to some pais-de-santo, there must be a relationship, a continuity between the medium and the spirit, and this is all part of the learning process, which involves controlling the emotions. The degree of consciousness of what happens during trance is something that is trained, but which also goes beyond individual embodiment and becomes a group embodiment as well: the group has to know how to react to certain performances. As Hess and Kirouac discuss (2000: 368-381), the membership in a social group directs the display of emotion and the recognition of these displays by the other group members. The social group, in this context, is defined loosely as members of a social category who share a common characteristic associated with shared beliefs or roles regarding emotionality. The família-de-santo in a terreiro forms what Appadurai (1996: 8) entitles a " community of sentiment', a group that begins to imagine and feel things together" (Rocha 2017: 9), which echoes some of the statements I collected in fieldwork:

"Once, we were having a ritual in the forest; my exú-mirim, whom, as you know, is a childish rascal, walked up to a couple of young homosexual boys, and yelled at them that they should accept their homosexuality. He spoke in a very natural way; at first, everyone who heard him shouting that was kind of embarrassed, but then the two boys started talking to the exú and publicly acknowledged their homosexuality... and of course all the group accepted that and felt totally at ease with the situation [...]. It is always like that: we, as a family (família-de-santo), share the emotions and learn how to handle them together." [Pai C.]

Far from being a field of total opening and laissez-faire, laissez passer, we have a case of expression of emotions allowed and sanctioned within a specific and well defined cultural and social setting (Lutz 1988; Lutz and Abu-Lughod 1990; Myers 1979), which comprehends a specific set of bodily codes, of multiple personalities embodied through a long and arduous learning process. Surely emotions and senses are there, but their expression is highly codified; the wild emotions that one feels when one starts his/her religious career are domesticated, as a pai-de-santo explained:

"At the beginning of my religious development, I felt fear, jealousy, revolt, love... the emotions were going through peaks... for example, once a simple 
argument with my father made me go into a trance (which I tried to hold), caused by an altered emotional state. [...]. Emotion and religion cannot walk apart. But people learn, throughout their development, to master and control emotions." [Interview Pai C.]

As Goldie discusses, emotions are complex, dynamic and structured, as "it constitutes part of a narrative - roughly, an unfolding sequence of actions and events, thoughts and feelings - in which the emotion itself is embedded." (Goldie 2000: 13)

\section{AUTHENTICITY, PERFORMANCE AND EMOTIONS}

The concept of "authenticity" in anthropology has been as controversial as the notion of "emotion" was following the publishing in Mind in 1884 of William James' essay "What is an emotion?" (Dixon 2012). All the above material illustrates how important the performative part of the Afro-Brazilian religions is, and how the aesthetics of such performances play a vital role in attracting followers. Performance brings us to the issue of authenticity in religion, and the issue of authenticity is indisputably an important one within the AfroBrazilian religions.

Debates around the notion of what is authentic in these religions are common and manifold: they discuss not only the authenticity of trance and possession, but also the authenticity of the religion itself. For many academics as well as many religious communities and leaders, only Candomblé keto - the traditional Candomblé from Bahia directly related to the Yoruba - is the authentic one, and all the other variants are just second-class versions. This purity leads to the importance of a direct connection with Africa and the false idea that the religions that came from Africa during the centuries of slave trade could have been frozen in time, in a way that one could nowadays still find the "pure" and "authentic" version of Candomble keto in the Bahia area, for instance, in some of the famous Candomblé terreiros, like Ilê Axê Opô Afonjá (Capone 2004a, 2004b). Within the multiple variants of the Afro-Brazilian religions, there are two major traditions where the matter of authenticity is widely discussed. Candomblé, which purports to be closer to the African roots and therefore more "authentic" (Capone 2004b); and Umbanda, which was formed later, only in the late $19^{\text {th }}$ century, and went through a process of whitening and pulling away from any African roots, considered backwards and primitive (Birman 1985; Brown 1999; Dantas 1988). ${ }^{22}$ In spite of all the discussions and publications illustrating how the 
issue of "authenticity" is a false one, especially nowadays when, in a scenario of expansion and transnationalization of these religions, they adapt to the various socio-cultural scenarios (Saraiva 2019), this debate remains present. What Bettina Schmidt (2016) concludes for the Brazilian context is in fact the rule everywhere, and definitely for the Portuguese scenario: with no central authority each religious leader chooses the trend he/she wants to follow.

A second sub-theme related to authenticity in the Afro-Brazilian religions deals with the fact that these religions (as other) encompass altered states of consciousness and possession. The common questions address the discussion on whether trance is real or faked, and how emotions and performance tie into this. In the edited volume Debating Authenticity (Fillitz and Saris 2013) the issue of authenticity is certainly key. In two of the chapters the authors analyze this notion, handling aspects of religion and performance that are relevant to the case presented in this paper.

Discussing the nature and validity of "authenticity", Rajko Mursic, in a text notably entitled "The deceptive tentacles of the authenticating mind: On authenticity and some other notions that are good for absolutely nothing", demonstrates how this concept has been inseparable from racism up to the present day (even if positive racism, for example, when one thinks that only Afro-Americans can do real rap) and culturalism/nationalism, when one is presented with the notion of "an authentic tradition of a people". As he states, in both cases the discourse of authenticity is an essentializing discourse (Mursic 2013: 47), and what is authentic for some people is inauthentic to others.

Although his chapter deals with authenticity in music, he goes on to expand on the authenticity of performance. He explains how there is always a moment when an artist loses control on stage, and how this loss of control is a very important part of a successful performance, as it provides a moment of communion of the performer with the public. Furthermore, this is the time when spontaneity comes in and emotions are shared with the audience. This is the experience of communion between the performer and the public. Yet, as the author stresses, chaos cannot settle in: "The musicians and the audience follow a scenario of the event and both perform their roles within parts of the performance." (Mursic 2013: 56)

Following Pattie's arguments (Pattie 1999 in Mursic 2013: 56), he goes on to say that "the best performance is thus a doubly faked event: a successful performance is a performance that denies that it is a performance; the moment of communion itself therefore rests upon a contradiction, in which overtly theatrical moments [...] are described as though they are displays of the performer's authentic, untheatrical self. Staged performance generates aesthetic, 
emotional and experiential effects from the inherent contradiction between carefully designed performance $[\ldots]$ and unpremeditated situations provoked by the responses of the audience or by force majeure." (Mursic 2013: 56). He then concludes the chapter by stating that in many spheres of present-day cultural creativity the notion of authenticity, with its manipulative character and seemingly unproblematic use, belongs to other essentializing and naturalizing notions that support regimes of exclusion and latent violence. He goes on to defend that "it is therefore time to abolish it altogether, with other similar notions that are good for absolutely nothing." (Mursic 2013: 58).

In our western tradition, the Other is the authentic/natural one, the representative of the lost ideal of Eden and innocence. The way the Portuguese perceive the Afro-Brazilian religions has to do with this notion of authenticity. The Portuguese followers of these religions dream of being able to one day go to Brazil or Africa, considered the religious Mecca for these religions. To go there empowers the person, as one moves closer to the origin of the sacred. This relates to the abovementioned idea that one becomes empowered through a bodily experience, trance and possession (as we have seen), that allows one to become a beautiful and supernatural entity. Such an experience is only possible by means of a connection with Africa and Brazil, as those gods originated there. Going to places such as these, considered the original grounds of these religions, is therefore a form of empowerment.

Besides that, the individuals that start practising these religions often come from a traditional Catholic background - having moved away from it - and are now willing to pick from the immense "religious supermarket" that is available to them in contemporary Portugal. They often combine different forms of alternative therapies - for example aromatherapy, gem therapy, reiki, fengshui, etc. - and new religious approaches, such as Wicca or New Age (Saraiva 2013a; Teisenhoffer 2007), in search of an inner self and a closer relationship to nature. As I have argued elsewhere, the conversion to the Afro-Brazilian religions comes with this willingness to try new things (Saraiva 2013a: 204). Another way the Portuguese get acquainted with Candomble is through music and art, or art as performance, as in Capoeira, a type of personal defense system that looks very much like a dance, and that has a history very similar to these religions. Taken to the New World by the African slaves, it became a Brazilian form of performance that is now exported and practiced all over the world. Once again, the aesthetics of this "dance-like fight" are important to understand its expansion (Brito 2013).

In my fieldwork interviews, the connections between ritual, emotion, performance and authenticity come up very vividly:

"I know that people that come to a xirê sometimes doubt if we are not just performing. I believe they think that because Candomblé is really a very 
theatrical religion, because of the movements, the dance, the music, the beating of the drums... and the beauty of the décor, of the colourful attire of the orixás. But this is not theatre, it is a lot of emotional work; the real incorporation is based on a strong emotional relationship between the medium and the spirit $[\ldots]$. When one starts in the religion, one is very often totally unconscious of what goes on while incorporated; but one learns to master a semi-consciousness, through the domestication of the emotions and the emotional relation with one's orixá." [Interview, Pai P.]

"It all has an emotional basis, and I also think this is also what attracts people to Umbanda and Candomblé; not only, for instance, the beauty of Candomblé dances, but also the fact that in the xirê the orixás involve everyone with their energy... you see, our emotions, when incorporated, are contagious to other people, even the ones that just come to watch, as if they would go to a theater play... and then people become involved... emotionally involved." [Interview, Candomblé follower]

Another contributor to the same volume on authenticity, Inger Sjorslev, in a chapter devoted specifically to the discussion of authenticity in the AfroBrazilian religions, explains how "Candomblé is very much a religion sustained by sociality, which is reflected mainly in the practice of ritual possession, while at the same time celebrating the individual" (Sjorslev 2013: 111), raising therefore questions concerning the relationship between collective acts and religious beliefs, and between outer forms of expression and inner feelings. The author defends that the phenomenon of possession in Candomble illustrates the relation between form and content, and the sociality of the performance points towards a subjective experience of authenticity.

Sjorslev takes a different stance from Mursic, in that he does not discard the concept of "authenticity", seeing it rather as an analytical one, pertaining to different emic discourses, and also as an empirical object - and therefore definitely one to be debated in the anthropological discipline (Sjorslev 2013: 112).

Discussing Schieffelin and his work with the Kaluli of New Guinea, he agrees with his conception that when people interact in ritualized or ceremonial manners meaning is created in the process (idem: 13), and states, following Goffman (1975), Bateson (1972) and MacAloon (1984), that performance is framed behavior, and that in performance we are also, as Schieffelin emphasizes, dealing with the production of meaning in practice. Drawing on Mitchell (2006), he stresses how performance can be further elaborated in anthropological thinking, linking it to materiality by pointing to the material transformations of body, things and space in performance. Sjorslev also mentions Bateson's notion that any utterance has to be understood and interpreted in 
its social context and cannot be limited to their cognitive or literal meaning; we must pay attention to the way people say things, to body language and other forms of non-verbal communication (Sjorslev 2013: 1 13-1 14). In addition, following Turner (1986), Sjorslev definitely sees ritual as a society's way of staging itself. Ritual puts a frame around what happens, and that frame can be fiction, as in theater, or a cosmology, as in religion - especially in religions like Candomblé:

"The gods are really there within the ritual frame; cosmologies become true, as Rappaport says, and it is the frame, which makes it true and acceptable. Rituals (re)create reality, as performance creates it continuously. So, in ritual and performance we are dealing with something very basic; we are, as more than one anthropological author since Durkheim has stated, at the core of what society is." (Sjorslev 2013: 115)

I cannot but agree with Sjorslev when he brings up Taylor's (1999) discussion of authenticity as related to modernity (and its malaise) and to the idea of "an inner core, a self in which the real, the sincere and the valuable is located in the inner constitution of the individual" (Sjorslev: 115). The idea is that a communitarian way of life and social commitment have been lost in modern life, and people have turned to individual values of authenticity: "The point is the fact that authenticity as a Western concept has become related to the individual and to an inner core, based on the tradition of Romanticism and going back to the Christian ideas of a personal self [...] the Candomblé ritual may be regarded as an example of the kind of reflexivity created by the joint event of individual possession and a collective, performative framework" (Sjorslev 2013: 116).

Indeed, as we saw before, the relationship between the gods and the individuals has a complex ontology to it, in addition to there also being a practice of learning to become a medium. The process of learning is a complex one, full of notions of "authenticity", as the apprentice wants to learn the "authentic" way of doing things as much as possible. In Portugal, the search for purity and authenticity relates to the origins of the religions, with the empowerment both the cult leaders and their followers attribute to the links they have with the motherlands of the Afro-Brazilian religions, Africa and Brazil.

The same happened to Sjorslev in an episode he recounts where he took a group of Danish college teachers of religion to Bahia, the reputed cradle of keto authenticity, where they observed and participated in several cult sessions, where performances of possession took place. The same group later went to São Paulo, where they witnessed yet another performance, in a religious group known as "traditionalist" (meaning: strictly adhering to what is perceived as a true Yoruba tradition and to an African past; from an emic perspective they 
consider themselves as returning to an authentic religious and ritual practice). Everything was so strictly according to their rules of authenticity that the Danish thought this was a fake, staged performance, not as "natural" as the ones they had seen in Bahia. In the São Paulo case, the performance needed the directive steering of the master of the show; in the Bahia ones, "there had been a feeling of being one body, a moving together, a feeling which included the audience, who gained a sense of being part of the whole performative body of dancers. A sense of some kind of organic sociality often emerged in Bahia, with those possessed by the orixás at the centre". In São Paulo there was a sense that something, some authenticity, was lacking: "The subjective experience was that something was lacking, and it had to do with the social habitus, the form of sociality, the way the collective moved, on the whole, the social choreography as such. This again points to the role of form in the immediate subjective impression of an authentic performance" (Sjorslev 2013: 119).

I agree with Sjorslev that the experience of something as authentic has to do with the transgression of the dichotomy of form and content, as well as with practice and human agency and with the sociality implied in performance. Just like in Lévi-Strauss' example of Quesalid, the Kwakiutl that became a great shaman and cured people because he learned to perform as a shaman, and not because he cured people: the collective consensus on what is authentic is of the utmost importance for symbolic efficacy.

Sjorslev also proposes that "when looking at authenticity as a process, materiality is a strong authentifier, and people elaborate the social and the material in transgressions of dichotomies between form and content, and also in transgressing the distinction between persons and things. In ritual contexts this may be seen as a kind of agency [...]. Whether a religious practice is regarded as authentic or not depends first of all upon the position of the observer. From an analytical point of view, it also depends upon power and agency, rhetoric and persuasion: as formulated by Stewart and Shaw in relation to syncretism (Stewart and Shaw 1994)." (Sjorslev 2013: 123)

The experience of whether a performance is or is not authentic has to do with the character of the sociality involved. Possession is without a doubt public performance, and the relation with the gods is achieved by means of gestures, actions, practices. The authenticity of the gods that are present derives from the audience who accepts them as real orixás. And the subjective experience of an authentic presence of gods again derives from the collective contribution to the performance. Performance creates a special kind of sociality which brings forward experiences of something authentic:

"It is the specific kind of sociality, which in a sense also creates those gods by which the dancers are possessed. The authenticity of possession thus lies in its performance, that is how form and content, inner and outer, 
come together, and in the holistic integration of the possessed with the audience and the whole social context" (Sjorslev 2013: 119).

In the case of the Afro-Brazilian religions, the matter of authenticity goes hand in hand with the attraction to beauty; the rituals that are considered more authentic are also the most colourful ones, the Candomble xirês. Nevertheless, such notions can come in various forms, and can certainly be modified and instrumentalized to suit one's needs. For instance, for the Portuguese Umbanda practitioners, the white immaculate dresses worn in the rituals are just as beautiful and "pure" as the colorful orixá ones in Candomblé.

For the followers, authenticity is directly related to emotions. An honest medium is one that has followed the correct/authentic career progress, has gone through all the initiations and ritual ceremonies. By going through this process, he/she will have mastered his/her emotions, and his/her emotional ties both to the spiritual entity (orixá for Candomblé, entities for Umbanda) that he/ she incorporates.

This relates to their perception of an authentic performance; for the followers both the xirê and the gira are hardly perceived as a performance, but as something deeply felt. But, although not acknowledging the performance part, they give voice to Schechner's proposals. For them, a xirê is a ceremony, where the magnificence of the Afro-Brazilian religions is played out, involving everyone present; for the spectators (as with the Sjorslev Danish group), it is a performative ritual. As Beeman (2007: 273-274) defends, humans do have a unique ability to perform in a way that affects the cognitive and emotional state of its audience; and human beings in every culture are extraordinarily engaged with performance. Since humans, like other primates, are fascinated by themselves, they enjoy it immensely, additionally spending energy and material resources to stage it. In the Afro-Brazilian religions, performance becomes routinized enough in the body so as not to require active attention to the physical details of executing it. The emotional involvement and the domestication of such emotions to adequately receive the spiritual entity echoes Bourdieu's notion of habitus. But also, as Beeman states, "it may be that trance states are the result of a particularly strong sense of flow" (2007: 279); the same type of (emotional) flow that Schechner (1993; Schechner and Appel 1990) analyse, as these authors discuss the use of one's real emotions in performance - just as individuals use them in their relationship with the spiritual entities that possess them, or in the interaction with the spectators of the religious ritual.

I would agree with Regina Bendix's notion of authenticity as a quality of experience, which changes from person to person and moment to moment. For the Portuguese who go to the Candomble and Umbanda terreiros, certainly aesthetics go hand in hand with authenticity, and become powerful symbols that draw them more and more towards these religions. As Henry John Drewal 
(2010) has explained for the case of Mami Wata worship among the Yoruba, ${ }^{23}$ we make sense of our world through our senses, and culture can be considered an aesthetic system at large, a sum of particular ways of being in the world, informed by body knowledge, which is shaped by the senses. For the Portuguese followers of the Afro-Brazilian religions, the Candomblé gods are authentic if they see them, worship them, and value them through their bodies and their senses.

\section{EMPATHETIC EMOTIONS}

As a final note, I would argue, like Helena Wulff, that the reflexive turn in anthropology which valorised the notion of empathy, must be taken seriously when studying religions and emotions. As she states: "Not only fieldworkers have feelings, so do the people we study" (2007: 3). This is echoed in Regina Bendix's idea (Bendix 2021) that when the ethnographer is trying to grasp experiences and sites of interaction where sensations are expressed in a culturally shared fashion, we may profit particularly from an expanded ethnographic sensibility and empathy. And relates even better to Renato Rosaldo's (1984) classical proposal to use one's own emotions and sensations to better grasp the other's (in this case the mediums, the spirits...) emotions.

Beyond empathy - or better, in order to reach empathy - one has to use one's senses, as Landes did: besides feeling and analysing the way women were central to the functioning of Afro-Brazilian religions in Bahia, she gave us the real impressionistic portrait of the life of those women, the gazes, the sounds and the scents of the "city of women". 


\section{REFERENCES}

ABREU, Regina, 2003, "A cidade das mulheres", Mana - Estudos de Antropologia Social, 9 (1): $151-154$.

ADOGAME, Afe, and James V. SPICKARD (eds.), 2010, Religion Crossing Boundaries: Transnational Religious and Social Dynamics in Africa and the New African Diaspora. Leiden and Boston: Brill.

APPADURAI, Arjun, 1996, Modernity at Large. Minneapolis: University of Minnesota Press.

ARGYRIADIS, Kali, and Stefania CAPONE (eds.), 2011 , La religion des orisha: Un champ social transnational en pleine recomposition. Paris: Hermann.

BAHIA, Joana, 2012, "A experiência da conversão: os relatos dos imigrantes brasileiros no candomblé europeu", Anais Eletrônicos XI Encontro Nacional de História Oral: Memória, Democracia e Justiça. Available at < http://www.encontro2012.historiaoral.org.br/resource s/anais/3/1337526783_ARQUIVO_AexperienciadaconversaoartigoJoanaBahia.pdf > (last access June 2021).

BAHIA, Joana, 2015a, "Exu na Mouraria: a transnacionalização das religiões afro-brasileiras e suas adaptações, trocas e proximidades com o contexto português", Revista Eletrónica Métis - História e Cultura, UCS, 14 (28): 111 -131.

BAHIA, Joana, 2015b, "A descoberta de Putamagal pelo Caboclo Pena Dourada", in Ari Pedro Oro e Donizete Rodrigues (eds.), A Transnacionalização Religiosa: Religiões em Movimento. Porto Alegre: Cirkula, 265-290.

BAHIA, Joana, 2020, "Where do prostitutes pray? On travestis, mães de santo, pombagiras and postcolonial desires”, in Martijn Oosterbaan, Linda Van De Kamp, and Joana Bahia (eds.), Global Trajectories of Brazilian Religion: Lusopheres. London: Bloomsbury Academic, 101-1 16. BARRETO, António (ed.), 2005, Globalização e Migrações. Lisbon: Instituto de Ciências Sociais. BARROS, José, and Maria Lina TEIXEIRA, 1989, "O código do corpo: inscrições e marcas dos orixás”, in Carlos Marcondes de Moura (ed.), Meu Sinal Está no Teu Corpo: Escritos sobre a Religião dos Orixás. São Paulo: Edicon/EDUSP, 36-63.

BASTOS, Cristiana, 2001, "Omulu em Lisboa: etnografias para uma teoria da globalização", Etnográfica, 5 (2): 303-324.

BATESON, Gregory, 1972, Steps to an Ecology of Mind. New York: Ballantine.

BEEMAN, William, 2007, "The performance hypothesis, practicing emotions in protected frames”, in Helena Wulff (ed.), The Emotions: A Cultural Reader. Oxford: Berg, 273-298. BENDIX, Regina, 2021, "Verbal art and the expression of the inexpressible: making sense of sensory experience”, Etnográfica, 25 (2): 513-538.

BIRMAN, Patrícia, 1985, O que É Umbanda. São Paulo: Editora Brasiliense.

BLANES, Ruy, 2009, "Remembering and suffering: memory and shifting allegiances in the Angolan Tokoist church”, Exchange, 38: 161-181.

BODDY, Janice, 1989, Wombs and Their Spirits: Women, Men and the Zar Cult in Northern Sudan. Madison: University of Wisconsin Press.

BOURGUIGNON, Erika, 2004, "Suffering and healing, subordination and power: women and possession practice", Ethos, 32 (4): 557-574.

BRENNEIS, Donald, 2005, "Afterword: sense, sentiment and sociality", Etnofoor, 18 (1): 142-149.

BRIGGS, Jean L., 1970, Never in Anger: Portrait of an Eskimo Family. Cambridge, MA: Harvard University Press. 
BRITO, Celso de, 2013, "The constitution of a transnational sphere of transcendence: the relationship between the Irmãos Guerreiros Capoeira Angola Group and Ilê Obá Silekê in Europe”, in Martijn Oosterbaan, Linda van de Kamp, and Joana Bahia (eds.), 2019, Global Trajectories of Brazilian Religion: Lusopheres. London: Bloomsbury Academic, 169-182.

BROWN, Diana, 1999, "Power, invention, and the politics of race: umbanda past and future", in Larry Crook and Randal Johnson, Black Brazil: Culture, Identity and Social Mobilization. Los Angeles: UCLA, 213-136.

CAPONE, Stefania, 1999, La quête de l'Afrique dans le candomblé: pouvoir et tradition au Brésil. Paris: Karthala.

CAPONE, Stefania, 2004a, A Busca de África no Candomblé: Tradição e Poder no Brasil. Rio de Janeiro: Pallas Editora.

CAPONE, Stefania (ed.), 2004b, "A propos des notions de globalisation et de transnationalisation", Civilisations - Revue Internationale d'Anthropologie et de Sciences Humaines, 51 : $1-22$.

CAPONE, Stefania, 2011, Os Yoruba do Novo Mundo. Rio de Janeiro: Pallas Editora.

CHESTNUT, Andrew, 2003, Competitive Spirits: Latin America's New Religious Economy. Oxford: Oxford University Press.

CORRIGAN, John, 2007, "The study of religion and emotions", in Michael Stausberg and Steven Engler (ed.), The Oxford Handbook of Religion and Emotions. Oxford: Oxford University Press, 3-13.

DANTAS, Beatriz G., 1988, Vovó Nagô e Papai Branco: Usos e Abusos da África no Brasil. Rio de Janeiro: Graal.

DIXON, Thomas, 2012, “Emotion': The history of a keyword in crisis”, Emotion Review, 4 (4): 338-344.

DREWAL, Henry J., 2010, "Material, sensorial religion: the case of Mami Wata", Material Religion, 5 (2): 226-229.

FAVRET-SAADA, Jeanne, 1977, Les mots, la mort, les sorts. Paris: Gallimard.

FEDELE, Anna, 2013, "The metamorphoses of neopaganism in traditionally catholic countries in Southern Europe", in Ruy Blanes and José Mapril (eds.), Sites and Politics of Religious Diversity in Southern Europe. Leiden: Brill, 51-72.

FILLITZ, Thomas, and Jamie A. SARIS, 2013, Debating Authenticity: Concepts of Modernity in Anthropological Perspective. New York: Berghahn Books.

FRIGERIO, Alejandro, 2004, "Re-Africanization in secondary religious diasporas: constructing a world religion", Civilisations - Revue Internationale d'Anthropologie et de Sciences Humaines, 51 (1-2, special issue): 39-60, Religions transnationales. Brussels: Université Libre de Bruxelles.

FRY, Peter, 1982, Para Inglês Ver. São Paulo, Brasiliense.

FRY, Peter, 1985, "Male homosexuality and spirit obsession in Brazil", Journal of Homosexuality, 11 (3-4): 137-154.

FRY, Peter, 2002, "Apresentação", A Cidade das Mulheres. Rio de Janeiro: UFRJ.

GOLDIE, Peter, 2000, The Emotions: A Philosophical Exploration. Oxford: Oxford University Press.

GOFFMAN, Erving, 1975, Frame Analysis: an Essay on the Organization of Experience. Harmondsworth: Peguin.

GUILlOT, Maia, 2009, “Du mythe de l'unité luso-afro-brésilienne: le candomblé et l'umbanda au Portugal”, Lusotopie, 16 (2): 205-219. 
HALLOY, Arnaud, 2001-2002, “Un candomblé en Belgique: traces ethnographiques d'une tentative d'installation et ses difficultés", Psychopathologie Africaine, XXI (1): 93-125.

HESS, Ursula, and Gilles KIROUAC, 2000, "Emotion expression in groups", in Michel Lewis and Jeannette Haviland-Jones, Handbook of Emotions. New York: The Guilford Press, 368-381 .

HOSCHILD, Arlie, 1983, The Managed Heart: Commercialization of Human Feeling. Berkeley: University of California Press.

LANDES, Ruth, 2002 [1947], A Cidade das Mulheres. Rio de Janeiro: Editora UFRJ.

LEWIS, Ioan M., 2003, Ecstatic Religion: A Study of Shamanism and Spirit Possession. London: Routledge ( $3^{\text {rd }}$ edition).

LUTZ, Catherine, 1988, Unnatural Emotions: Everyday Sentiments on a Micronesian Atoll and Their Challenge to Western Theory. Chicago: The University of Chicago Press.

LUTZ, Catherine, and Lila ABU-LUGHOD (eds.), 1990, Language and the Politics of Emotion. Cambridge: Cambridge University Press.

LUTZ, Catherine, and Geoffrey WHITE, 1986, "The anthropology of emotions", Annual Review of Anthropology, 26 (4): 910-932.

MACALOON, J., 1984, "Introduction: cultural performances, cultural theory", in John MacAloon (ed.), Rite, Drama, Festival, Spectacle: Rehearsals Toward a Theory of Cultural Performance. Philadelphia: ISHI, 1-15.

MACHADO, Fernando, 2002, Contrastes e Continuidades: Migração, Etnicidade e Integração dos Guineenses em Portugal. Oeiras: Celta.

MAFrA, Clara, 2002, Na Posse da Palavra. Lisboa: Imprensa de Ciências Sociais.

MALHEIROS, Jorge, 2005, "Jogos de relações internacionais: repensar a posição de Portugal no arquipélago migratório global”, in António Barreto (ed.), 2005, Globalização e Migrações. Lisbon: ICS, 237-256.

MATORY, J. Lorand, 1988, "Homens montados: homossexualidade e simbolismo da possessão nas religiões afro-brasileiras", in João José Reis (eds.), Escravidão e Invenção da Liberdade: Estudos sobre o Negro no Brasil. São Paulo: Brasiliense, 215-231.

MATORY, J. Lorand, 2005, Black Atlantic Religion. Tradition, Transnationalism and Matriarchy in the Afro-Brazilian Candomblé. Princeton: Princeton University Press.

MATTHEWS, Gareth, 1980, "Ritual and the religious feelings", in Amélie Rorty (ed.), Explaining Emotions. Berkeley: University of California Press, 339-353.

MITCHELl, Jon P., 2006, "Performance", in Christopher Tilley et al. (eds.), Handbook of Material Culture. London: Sage, 384-401.

MOUTINHO, Laura, 2013, "Homosexuality, skin color and religiosity: flirting among the 'povo de santo' in Rio de Janeiro”, in Horacio Sívori et al., Sexuality, Culture and Politics - A South American Reader. Rio de Janeiro: CLAM, Latin American Center on Sexuality and Human Rights, 573-592.

MURSIC, Rajko, 2013, "The deceptive tentacles of the authenticating mind: On authenticity and some other notions that are good for absolutely nothing", in Thomas Fillitz and Jamie A. Saris (eds.), 2013, Debating Authenticity: Concepts of Modernity in Anthropological Perspective. New York: Berghahn Books,46-62.

MYERS, F., 1979, "Emotions and the self: a theory of personhood and political order among Pintupi aborigines”, Ethos, 7 (4): 373-370.

ORO, Ari Pedro, 1995, "A desterritorialização das religiões Afro-Americanas", Horizontes Antropológicos, 1 (3): 69-79. 
ORO, Ari Pedro, and Carlos STEIL (orgs.), 1997, Religião e Globalização. Petrópolis: Vozes. PORDEUS JR., Ismael, 2000, Uma Casa Luso-Afro-Portuguesa com Certeza: Emigrações e Metamorfoses da Umbanda em Portugal. São Paulo: Terceira Margem.

PORDEUS JR., Ismael, 2009, Portugal em Transe. Lisboa: Imprensa de Ciências Sociais.

ROCHA, Cristina, 2017, John of God: The Globalization of Brazilian Faith Healing. Oxford: Oxford University Press.

ROSALDO, Renato, 1984, "Grief and a Headhunter's rage: on the cultural force of emotions”, in Edward Bruner, Play, Text and Story. Proceedings of the 1983 meeting of the American Ethnological Society. Washington DC.

ROSSBACH DE OLMOS, Lioba, 2009, "Santería abroad: the short history of an Afro-Cuban religion in Germany by means of biographies of some of its priests", Anthropos, 104: 483-497.

ROUSSOU, Eugenia, 2017, “The syncretic religious landscape of contemporary Greece and Portugal: a comparative approach on creativity through spiritual synthesis", in Stefania Palmisano and Nicola Pannofino (eds.), Invention of Tradition and Syncretism in Contemporary Religions: Sacred Creativity, Palgrave Studies in New Religions and Alternative Spiritualities. Cham, Switzerland: Springer International Publishing, 155-175.

SANTOS, Milton S., 2008, "Sexo, género e homossexualidade: o que diz o povo de santo paulista”, Horizonte, 6 (2): 145-156.

SARAIVA, Clara, 2007, "African and Brazilian altars in Lisbon: some considerations on the reconfigurations of the Portuguese religious field", in Nancy Naro, Roger Sansi-Roca and David Treece (eds.), Cultures of the Lusophone Black Atlantic. New York: Palgrave Macmillan, 175-196.

SARAIVA, Clara, 2008, "Transnational migrants and transnational spirits: an African religion in Lisbon", in R. Grillo and V. Mazzucato (eds.), Journal of Ethnic and Migration Studies, special issue, 34 (2): 253-270

SARAIVA, Clara, 2010a, "Afro-Brasilianische Rituale und Therapien in Portugal", in Hansjörg Dilger and Bernhard Hadolt (eds.), Medizin im Kontext: Krankheit und Gesundheit in einer vernetzten Welt. Frankfurt Am Main/New York: Peter Lang, 181-200.

SARAIVA, Clara, 2010b, "Filhas de santo: rituais, terapias e diálogos afro-brasileiros em Portugal", in Philip Havik, Clara Saraiva, and José A. Tavim (eds.), Caminhos Cruzados em História e Antropologia: Estudos de Homenagem a Jill Dias. Lisboa: Imprensa de Ciências Sociais, 341-365.

SARAIVA, Clara, 2010c, "Afro-Brazilian religions in Portugal: bruxos, priests and pais de santo", Etnográfica, 14 (2): 265-288.

SARAIVA, Clara, 2011, "Energias e curas: a umbanda em Portugal", Revista Pós Ciências Sociais, 8 (16): 55-76.

SARAIVA, Clara, 2013a, "Pretos-velhos across the Atlantic - Afro-Brazilian cults in Portugal", in Manuel Vasquez and Cristina Rocha (eds.), The Diaspora of Brazilian Religions. London: Brill, 197-222.

SARAIVA, Clara, 2013b, "Blood, sacrifices and religious freedom: Afro-Brazilian associations in Portugal”, in José Mapril and Ruy Blanes (eds.), Sites and Politics of Religious Diversity in Southern Europe: The Best of All Gods, International Studies in Religion and Society Series. Leiden: Brill, 129-156.

SARAIVA, Clara, 2016, "Circulating spirits and dead bodies: funerary transnationalism among immigrants from Guinea Bissau in Portugal”, African Diaspora, 9 (1-2): 1-16. 
SARAIVA, Clara, 2019, "Our Lady of Fatima in Brazil, and Iemanjá in Portugal: Afro-Brazilian religions across the Atlantic”, in Ramon Sarró, Ruy Blanes and Markus Balkenhol (eds.), Atlantic Perspectives: Places, Spirits, and Memories in Africa, the Americas and Europe. New York and Oxford: Berghahn, 159-151.

SARRÓ, Ramon, and Ruy Llera BLANES, 2010, "Profetas e missionários: reflexões sobre as igrejas angolanas em Lisboa", in Helena Vilaça and Enzo Pace (eds.), Religião em Movimento: Imigrantes e Diversidade Religiosa em Portugal e Itália. Porto: Estratégias Criativas: $141-153$.

SCHECHNER, Richard, 1993, The Future of Ritual. London and New York: Routledge.

SCHECHNER, Richard, and Willa APPEL (eds.), 1990, By Means of Performance. Cambridge and New York: Cambridge University Press.

SCHMIDT, Bettina, 2008, Caribbean Diaspora in the USA: Diversity of Caribbean Religion in New York City. Oxon: Ashgate.

SCHMIDT, Bettina, 2016, Spirit and Trance in Brazil: An Anthropology of Religious Experience. London: Bloomsbury.

SEF - Serviço de Estrangeiros e Fronteiras, 2019, Relatório de Imigração, Fronteiras e Asilo 2019. Lisboa: SEF. Available at < https://sefstat.sef.pt/Docs/Rifa2019.pdf > (last access June 2021).

SILVA, Vagner G., 1995, Orixás da Metrópole. São Paulo: Vega.

SJORSLEV, Inger, 2013, "Is form really primary or, what makes things authentic? Sociality and materiality in Afro-Brazilian ritual and performance", in Thomas Fillitz, and Jamie A. Saris, Debating Authenticity: Concepts of Modernity in Anthropological Perspective. New York: Berghahn Books, 11 1-127.

STEWART, Charles, and Rosalind SHAW, 1994, Syncretism/Anti-Syncretism: The Politics of Religious Synthesis. London and New York: Routledge.

SVASEK, Maruska, 2005, "Introduction: emotions in Anthropology", in Kay Milton and Marushka Svasek (eds.), Mixed Emotions: Anthropological Studies of Feelings. Oxford: Berg, $1-23$.

TAYLOR, Charles, 1999, The Ethics of Authenticity. Cambridge, MA, and London: Harvard University Press.

TEISENHOFFER, Viola, 2007, "Umbanda, new age et psychothérapie: aspects de l'implantation de l'umbanda à Paris", Ateliers du LESC, 31, Religions afro-américaines: nouveaux terrains, noveaux enjeux. Available at < https://journals.openedition.org/ateliers/872 > (last access June 2021).

TURNER, Victor, 1986, The Anthropology of Performance. New York: PAJ Publications.

VALA, Jorge, 1999, Novos Racismos: Perspectivas Comparativas. Oeiras: Celta.

VILAÇA, Helena, 2006, Da Torre de Babel às Terras Prometidas: Pluralismo Religioso em Portugal.

Porto: Afrontamento.

VILAÇA. Helena, Enzo PACE, Inger FURSETH, and Per PETERSSON (eds.), 2016, The Changing Soul of Europe: Religions and Migrations in Northern and Southern Europe. London: Routledge.

WULFF, Helena (ed.), 2007, The Emotions: A Cultural Reader. Oxford: Berg. 